\title{
On the condensation of aqueous vapour in capillary spaces
}

\section{G. Van Der Mensbrugghe}

To cite this article: G. Van Der Mensbrugghe (1891) On the condensation of aqueous vapour in capillary spaces, Philosophical Magazine Series 5, 31:188, 74-74, DOI: 10.1080/14786449108620073

To link to this article: http://dx.doi.org/10.1080/14786449108620073

曲 Published online: 08 May 2009.

Submit your article to this journal

Џ Article views: 3

Q View related articles $\asymp$ 
Hence $\mathrm{T}$ is proportional neither to $\lambda$ nor to $\lambda^{2}$.-Exner's Repertorium der Physik, xxvi. p. 102 (1890); Beiblätter der Physik, xiv. p. 938 .

\section{ON THE CONDENSATION OF AQUEOUS VAYOUR IN CAPILLARY SPACES. BY G. VAN DER MENSBRUGGHE.}

The author propounds the task of furnishing an exact experimental proof of Thomson's theory, that the maximum pressure of aqueous vapour for a given temperature is smaller for a concave surface than for a plane one, and continually decreases with increasing concavity. In the first part of the present research a number of facts are collected which serve as examples for the condensation of aqueous vapour in capillary spaces. Mention is made of the microscopic capillary slits in organic hygroscopic structures, the deposition of ice-flowers on the dusty parts of our window-panes, the phenomenon that particles of iron rust most when they appear protected by materials, such as cloths, dry wood, and the like, which are in contact with them.

In reference also to Aitken's experiments on the fog-producing uction of suspended particles of dust, the author urges as the explanation the irregular shape and the ultra-capillary cracks of the individual particles. The author observes incidentally, that the rapid rotting of fabrics, such as talle, which are often coated with aqueous vapour even in air which is far from its point of saturation, may be explained by thermoelectric currents which are formed on moistening and on drying (Bull. Ac. Belg. [2] vol. xli. p. 769,1876$)$. The durability of the clothing with which Egyptian mummies are wrapped depends on the filling of the capillary cracks with wax. The author strongly recommends that for the preservation of oil-paintings they should be varnished on the back. - Bull. Ac. Belg. [3] vol, xix. p. 101 (1890); Beiblätter der Physik, No. 11, 1890 .

\section{ON FLECTRICAL CONVECTION. BY A. RIGHI.}

In this note the author describes new experiments, which taken in conjunction with those he has previously published appear to him to establish:-

That in all cases in which there is an escape of electricity either by a point, or by an incandescent body, or by a metal exposed to uitra-violet radiations, the phenomenon is due to convection; and that the particles in movement follow sensibly the lines of force of the field in which they move. In more or less rarefied air the trajectories seem to diverge more and more from the lines of force; and in the case of an extreme degree of rarefaction they should become almost rectilinear, as appears to be the case with the particles of radiant matter in Crookes's tubes.

The autbor proposes to make experiments to see if this gradual 